\title{
Attitudes towards mobile marketing tools: A study of Turkish consumers
}

Received (in revised form): 4th December, 2007

\section{Süleyman Barutçu}

is an assistant professor of Marketing at Pamukkale University in Denizli, Turkey. He earned his MBA degree at Fairleigh Dickinson University, NJ, USA, and PhD degree from Dokuz Eylül University, İzmir, Turkey. He has studied about information technology, customer loyalty, relationship marketing, mobile marketing and supply chain management. He has published several articles and papers in scientific journals, national and international congresses, and has given numerous seminars about supply chain management and more recently, about mobile marketing.

\section{Keywords mobile commerce, mobile marketing, consumer behaviour}

\begin{abstract}
This study analyses the possible significant impacts of mobile phone technology developments on marketing and determines those target mobile phone users who have the most positive attitudes towards mobile marketing tools. The survey results, conducted on 418 mobile phone users, show that the mobile phone users' adaptation to mobile shopping is low; however, mobile phone users have positive attitudes towards mobile marketing tools - mobile advertising, mobile discount coupons, mobile entertainment, location-based mobile services, mobile internet and mobile banking. The survey results suggest that target segment/segments can be determined for mobile marketing strategies. Managerial implications and recommendations are also offered that may work to increase mobile commerce and marketing adaptation rates.

Journal of Targeting, Measurement and Analysis for Marketing (2007) 16, 26-38. doi:10.1057/palgrave.jt.5750061
\end{abstract}

\section{INTRODUCTION}

One of the marketer's demands is to be able to communicate with potential customers and to contact them anywhere and anytime. The mobile phone has made a revolutionary contribution towards this objective. Scharl et al. ${ }^{1}$ define mobile marketing as using a wireless medium to provide consumers with time- and location-sensitive, personalised information that promotes products, services and ideas, thereby benefiting all stakeholders. Yuan and Cheng $^{2}$ emphasise that mobile marketing is becoming increasingly popular because the mobile phone is such a personal device.

The rapid growth of mobile phone has led to the development of a new term: mobile

Correspondence: Süleyman Barutçu, Pamukkale Üniversitesi, İ.İ.B.F. İșletme Bölümü, Kınıklı Kampüsü, 200070, Kınıklı/Denizli, Turkey. Tel: + 902582952702 ;

GSM: +90 5425868517 ;

Fax: + 902582952792 ;

E-mail: sbarutcu@pau.edu.tr commerce. In the literature, all mobile commerce definitions are very similar. In principle, any transaction with a monetary value conducted via mobile communication networks can be considered mobile commerce. ${ }^{3}$ Siau et al. ${ }^{4}$ define mobile commerce as a new type of e-commerce transaction conducted through mobile devices using wireless telecommunication networks and other wired e-commerce technologies; Clarke ${ }^{5}$ defines mobile commerce as the application of wireless communications networks and devices to the execution of transactions with monetary value; Frolick and Chen ${ }^{6}$ define mobile commerce as any form of mobile communication between a business and its customer; Dholakia and Dholakia ${ }^{7}$ define mobile commerce for electronic commerce transactions carried out via mobile phones and wireless terminals; and Bai et al. ${ }^{8}$ simply identify as the transaction conducted over a wireless telecommunication network, either directly or indirectly. Briefly, mobile commerce can be understood as a business model that allows 
a consumer to complete all steps of a commercial transaction using a mobile phone. ${ }^{9}$

The growth and use of mobile commerce as an emerging technology has the potential to dramatically change the way consumers conduct transactions. Mobile commerce driven by wireless communication technology is also generating interest among marketers. ${ }^{10}$ Therefore, the penetration of this new technology has led to changes in advertising, retailing and shopping in marketing, and companies wishing to make business in mobile markets should be ready for mobile marketing and mobile commerce.

Although similar in many respects to internetbased e-commerce, mobile commerce has some core characteristics that differentiate it from classic e-commerce. ${ }^{11}$ These include: (1) ubiquity being available at any time and any location; (2) personalisation - while mobile hardware has limited memory capacity, software can enable a finer degree of sorting and categorisation to meet the mobile phone users' needs, (3) flexibility the mobile phone permits the user to conduct transactions and/or receive information even when they are engaged in another activity such as travelling or working, (4) dissemination originators of information (for example local retailers) may use the wireless network of mobile commerce to deliver specific information to customers, ${ }^{3,4}$ (5) convenience - convenient for users to operate, (6) instant connectivity - the marketer can easily connect to target customers and (7) location - location-specific information and products can be provided. ${ }^{6}$

Even though companies are investing heavily in mobile commerce and mobile marketing, the nature and implications of this channel have yet to be fully understood and studies need to be performed to gain an insight into how best to utilise it. ${ }^{12}$ The main objective of this study is to draw Global System for Mobile Communications (GSM) operators' and entrepreneurs' attention to new opportunities in mobile commerce and mobile marketing. In this study, (1) mobile commerce and mobile marketing concepts, (2) mobile marketing tools, (3) the importance of mobile marketing in Turkey and (4) the consumers' attitudes towards mobile marketing tools are explained and analysed. The results of a survey conducted with 418 mobile phone users so as to determine consumers' attitudes towards mobile shopping and mobile marketing are provided.

\section{MOBILE COMMERCE AND MOBILE MARKETING}

\section{Mobile commerce services and businesses}

Mobile commerce is a service-based business. Various attempts at classification of existing and possible mobile commerce services have been made in the literature. Some of these ${ }^{13}$ are summarised in Figure 1. Funk ${ }^{14}$ analysed potential mobile service applications and identified seven applications relevant to business: (1) multi-media mail; (2) mobile phones as portable entertainment players; (3) mobile marketing; (4) mobile shopping; (5) navigation; (6) use in lieu of tickets and money; and (7) mobile intranet applications.

In addition to e-commerce, mobile commerce creates new markets among producers, distributors, retailers and customers anywhere and at any time. As can be seen in Figure 2, and in common with frameworks for classifying electronic commerce, mobile commerce models are divided into B2B (business to business), B2C (business to customer) and $\mathrm{C} 2 \mathrm{C}$ (consumer to consumer) perspectives.

B2B mobile commerce refers to the transactions among suppliers, producers, wholesaler, distributors, retailers and logistics service providers conducted over mobile phone and wireless technology. C2C mobile commerce is an emerging area to buy and sell products and services over the mobile phone within mobile commerce. In this type of commerce, mobile phone users sell their products and services or second-hand products to other mobile phone users/customers. B2C mobile commerce refers to the selling and buying of products and services via the mobile phone to mobile customers. B2C mobile commerce is composed of three parts: GSM operators or retailers, customers and logistics providers. GSM operators or retailers adopt a 'pull' promotion strategy towards 


\begin{tabular}{|c|c|c|c|c|c|c|c|}
\cline { 3 - 5 } \multicolumn{10}{|c|}{ B2C Mobile Commerce Services } \\
\hline $\begin{array}{c}\text { Mobile } \\
\text { Commerce }\end{array}$ & $\begin{array}{c}\text { Mobile } \\
\text { Shopping }\end{array}$ & $\begin{array}{c}\text { Dynamic } \\
\text { Information } \\
\text { Management }\end{array}$ & Entertain & $\begin{array}{c}\text { Information } \\
\text { Service }\end{array}$ & $\begin{array}{c}\text { Mobile } \\
\text { Advertising }\end{array}$ & $\begin{array}{c}\text { Mobile } \\
\text { Security \& } \\
\text { Emergency }\end{array}$ & $\begin{array}{c}\text { Personal } \\
\text { Interaction }\end{array}$ \\
\hline $\begin{array}{c}\text { Banking } \\
\text { Brokerage }\end{array}$ & $\begin{array}{c}\text { Retailing } \\
\text { Ticketing } \\
\text { Auctions } \\
\text { Reservation }\end{array}$ & $\begin{array}{c}\text { Loyalty } \\
\text { Programs } \\
\text { Medical } \\
\text { Records } \\
\text { Mobile } \\
\text { Membership }\end{array}$ & $\begin{array}{c}\text { Gaming } \\
\text { Gambling } \\
\text { Music } \\
\text { Postcards } \\
\text { Video }\end{array}$ & $\begin{array}{c}\text { News } \\
\text { Directories } \\
\text { Maps } \\
\text { Traffic } \\
\text { Information } \\
\text { Directions }\end{array}$ & $\begin{array}{c}\text { Coupons } \\
\text { One-to-One } \\
\text { Marketing } \\
\text { Promotion }\end{array}$ & $\begin{array}{c}\text { Emergency } \\
\text { Child, } \\
\text { Person, } \\
\text { Health } \\
\text { Tracking }\end{array}$ & $\begin{array}{c}\text { E-Mail } \\
\text { Calendars } \\
\text { Chat Rooms } \\
\text { Communities } \\
\text { Unified } \\
\text { Messaging }\end{array}$ \\
\hline
\end{tabular}

Figure 1: B2C mobile commerce service classifications

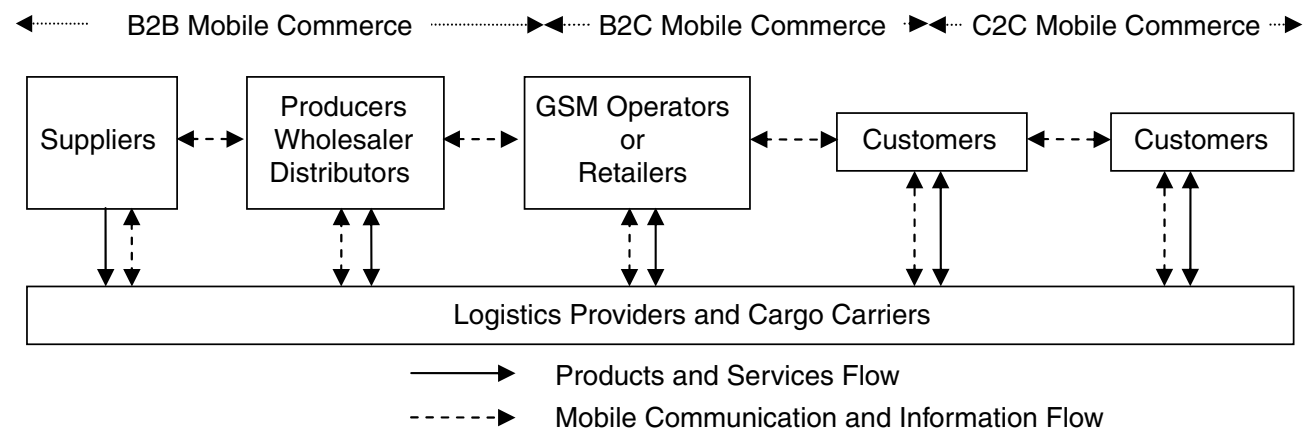

Figure 2: The parts of mobile commerce and mobile marketing

customers with mobile phones in order to market and sell products and services. Customers can order products and services via the mobile phone and purchase them. Logistics providers carry them from warehouses or stores to customers.

\section{Mobile marketing tools}

Mobile advertising, mobile sales promotion, mobile entertainment services, location-based mobile services, mobile internet, mobile banking and mobile shopping stand out as the critical mobile marketing tools.

(i) Mobile advertising: A key component of mobile marketing communication is advertising, either in a push or a pull mode. After obtaining the consumer's permission, push advertising sends relevant but not explicitly requested text and video messages. Quah and $\mathrm{Lim}^{15}$ argue that the push model will dominate mobile advertising since it saves consumers' time and money compared to browsing content. Mobile retailers can send SMS (Short Message Services) and MMS (Multimedia Message Service) advertisements to their potential customers. Many brands and media companies include text message numbers in their advertisements to enable interested consumers to obtain more information. This mode of advertising takes advantage of valuable channels of wireless communication to enhance customer relationships, and to carry out direct marketing and promotional activities. ${ }^{6}$ By using MMS, marketers can benefit from the use of photos, music, logos and animation and videos. SMS and MMS advertisements are expected to achieve higher response rates than that of e-mail or television because all advertisements can be sent personally. 
(ii) Mobile sales promotion: Mobile coupons in sales promotion play a vital role, and marketers can predict a higher usage of mobile compared to their paper-based equivalents. Mobile coupons boast at least three advantages: locating by mobile phone signals, time sensitivity and efficient handling by scanning the coupon's bar code at the point of sale. ${ }^{1}$

(iii) Mobile entertainment: The mobile phone has become an important media and entertainment platform. In the mobile entertainment industry, there are several entertainment services like listening to music, playing games, gambling, watching television, video and sport matches, etc, which have set a stage for an explosion of the mobile entertainment industry. There is no doubt that mobile entertainment services will be one of the most important drivers in mobile marketing.

(iv) Location-based mobile services: Location-based mobile services play a significant part in B2C mobile commerce. The vast majority of uses for location-based mobile services are likely to be commercial, involving the provision of specific services adapted to individual profiles and their location. ${ }^{16}$ Location-based mobile services are the services in which the location of a person or an object is used to shape or focus the application or service. 'What is near me?' or 'where is the nearest restaurant?' questions can be answered with these location-based services in mobile commerce. The ability to identify the customer's location at a point in time is one of the most promising applications of mobile commerce. ${ }^{17,18}$ By using the information on the users' identity, position, access time and profiles, GSM operators or retailers can offer the users optimal information or services, which are contextually relevant to them at the point of need, ${ }^{19}$ and the customers' location data can be used for direct marketing purposes. ${ }^{16}$

(v) Mobile internet: By using new browsers and other mobile applications, the new range of mobile technology offers the internet 'in user pocket' for which the user possibilities are endless, including banking, booking or buying tickets, shopping and real-time news. ${ }^{20}$ All GSM operators offer mobile internet applications in Turkey. When using the mobile internet, mobile phone users can have access to all web pages via mobile phone without computer.

(vi) Mobile banking: Mobile banking allows mobile phone users to do their banking transactions outside of the bank hours. They can use their mobile phones to check the balance on their accounts, account transactions, pay their bills, transfer funds, etc and manage their accounts wherever and whenever they want. Nowadays, several banks have launched mobile applications that will allow customers to get banks' services in Turkey.

(vii) Mobile shopping: The mobile phone is the most exciting tool to expand customers' shopping options, only secondary to the internet. At first, the mobile phone may seem like a scary place to shop; however, mobile phone users can go online to buy just about anything they need or want. Used properly, mobile shopping is a new, easy, practical and price-conscious shopping tool. The sudden growth of mobile shopping has placed mobile retailers at the consumers' fingertips, and has allowed mobile phone users to purchase nearly anything they desire without ever leaving their houses and offices.

\section{Mobile phone penetration and mobile services in Turkey}

During the past decade, mobile phones have surged to the forefront of the Turkish telecommunications industry. The mobile communications market has enjoyed rapid growth since 1994 in terms of the numbers of GSM (Global System for Mobile Communications) operators and subscribers in Turkey. In September 2007 , the number of mobile phone subscribers exceeded 60 million $(60,652,682) .{ }^{21}$

The importance of mobile marketing can be analysed in comparison to the mobile phone and the internet penetration rates in Turkey. The availability of personal computers and internet users are low, at about 6.67 per 100 households and 13.93 per 100 population within the last three months (April-June, 2007), respectively. While by the end of 2004,50 per cent of population had adopted mobile phones, this percentage increased to 80 per cent by the end of September 2007. ${ }^{22}$ 
The mobile market in Turkey turns out to be distinctive by comparison with some developed countries. For example, the internet penetration rate in EU countries is higher than that in Turkey. As a result, Turkish consumers might see a greater need for mobile internet over fixed line connections. Moreover, Turkey has demographic characteristics different from that of many developed countries. It has a huge population of young people, 45 per cent of whom are less than 25 years old, and this young population is still on the increase because of high birth rates. A low fixed-line internet penetration rate and a high proportion of young mobile phone users present a key opportunity for mobile internet and mobile marketing.

By October 2007, mobile marketing applications were increasing but had yet to become fully established in Turkey. Most activity is mainly in relation to promotion (mobile advertising, sales promotion and public relations), mobile internet and mobile banking rather than to commercial transactions. An exception is the mobile entertainment service; all Turkish GSM operators offer some form of mobile entertainment service.

\section{MOBILE PHONE USERS' ATTITUDES TOWARDS MOBILE COMMERCE AND MARKETING}

What are Turkish mobile phone users' attitudes towards the use of mobile marketing tools? Barutçu ${ }^{23}$ investigated consumers' attitudes towards mobile advertising, entertainment, discount coupons and shopping. The results of his survey indicated to that apart from mobile shopping, consumers have positive attitudes towards mobile advertising, entertainment and discount coupons. Tsang et al. ${ }^{24}$ investigated consumers' attitudes toward mobile advertising and the relationship between attitude and behaviour. The results of their survey indicated that consumers generally had negative attitudes towards mobile advertising unless they had specifically consented to receive the advertising messages. The objectives of this study are to (1) investigate the market status of mobile commerce, (2) bring to light mobile phone users' attitudes towards mobile marketing tools and (3) determine the target segment/segments and the best demographic characteristics of mobile phone users for such tools. Research questions and hypotheses are formulated to shed light on mobile phone users' attitudes towards mobile marketing (Figure 3).

$\mathbf{H}_{1}$ : Mobile phone users have positive attitudes towards mobile marketing tools.

$\mathbf{H}_{\mathbf{2}}$ : There are differences between respondents' demographics characteristics and attitudes towards mobile marketing tools.

$\mathbf{H}_{3}$ : There are differences between respondents' shopping orientations and attitudes towards mobile marketing tools.

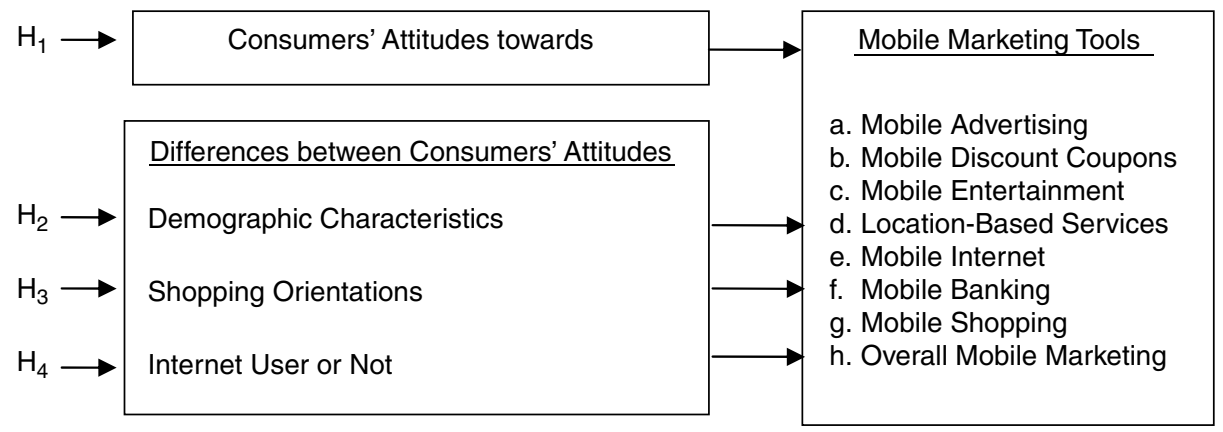

Figure 3: Research framework for consumers' attitudes towards mobile marketing tools 
$\mathbf{H}_{4}$ : There are differences between noninternet users' and internet users' attitudes towards mobile marketing tools.

All these hypotheses are based on a combination of seven sub-hypotheses. For example, in hypothesis $\mathrm{H}_{1}$, they have positive attitudes towards mobile advertising $\left(\mathrm{H}_{1 \mathrm{a}}\right)$, mobile coupons and discounts $\left(\mathrm{H}_{1 \mathrm{~b}}\right)$, mobile entertainment $\left(\mathrm{H}_{1 \mathrm{c}}\right)$, location-based mobile services $\left(\mathrm{H}_{1 \mathrm{~d}}\right)$, mobile internet $\left(\mathrm{H}_{1 \mathrm{e}}\right)$, mobile banking $\left(\mathrm{H}_{1 \mathrm{f}}\right)$, mobile shopping $\left(\mathrm{H}_{1 \mathrm{f}}\right)$ and overall mobile marketing $\left(\mathrm{H}_{1}\right)$. These alternative hypotheses and sub-hypotheses are tested below.

\section{Research methodology}

Data for this research were collected through a questionnaire survey. The questionnaire and attitude statements were developed from the existing literature ${ }^{12,23,25}$ and self-created. The survey questionnaire consisted of 32 questions. The first five questions were designed to elicit the demographic characteristics of the respondent. One question was related to determining whether the respondent is an internet user or not. One question was related to categorising the respondents in terms of their shopping orientations, and 20 questions were intended to investigate mobile phone users' attitudes towards mobile marketing tools. The last five questions (not analysed in this paper) were related to the products and services marketed via mobile phones. Attitudes towards mobile marketing services were measured by means of 20 questions (eg 'I find receiving advertisement via the mobile phone positive', 'I find mobile shopping suitable' and 'My general intention to shop via mobile phone is very high', etc) that the respondents marked using a five-point scale (1 strongly disagree; 2 disagree; 3 neither disagree nor agree; 4 agree and 5 strongly agree).

The questionnaire was pre-tested by 12 mobile phone users in order to construct the validity of the measurement scale. In the sampling stage, systematic sampling was implemented for selecting respondents and judgment sampling was implemented for selecting shopping centres. A
Table 1: Summary of items' measures

\begin{tabular}{lcl}
\hline Mobile marketing tools & $\begin{array}{l}\text { Number of } \\
\text { questions }\end{array}$ & $\begin{array}{l}\text { Cronbach } \\
\text { alpha }\end{array}$ \\
\hline $\begin{array}{l}\text { a. Mobile advertising } \\
\text { b. Mobile discount coupons }\end{array}$ & 4 & 0.9276 \\
$\begin{array}{l}\text { c. Mobile entertainment } \\
\quad \text { services }\end{array}$ & 3 & 0.8545 \\
d. Location-based mobile & 3 & 0.8011 \\
$\quad$ services & & 0.7630 \\
e. Mobile internet & 2 & 0.8792 \\
f. Mobile banking & 3 & 0.9513 \\
g. Mobile shopping & 3 & 0.7953 \\
h. Overall mobile marketing & 20 & 0.8273 \\
\hline
\end{tabular}

total of 440 questionnaires were distributed randomly in the 11 shopping centres in four cities (Ankara, izmir, Eskişehir and Denizli). SPSS 13.0 for Windows was used to analyse the data.

The reliability of the questionnaires was assessed by the Cronbach alpha reliability coefficient. Reliability value was calculated as 0.8273 and exceeded the suggested value of 0.70 . Table 1 summarises all the properties of the items. The Cronbach alpha values indicate that all measures have good internal consistency with values above 0.70 . The reliabilities of the measures of the constructs, ranging from 0.7630 to 0.9513 , were good.

Table 2 indicates the correlation matrix of mobile marketing services, where correlation coefficients between variables that belong to the same constructs are clearly higher than others, suggesting the internal consistency of multi-item measures. The survey results demonstrated in Tables 1 and 2 have high reliability and there are grounds for further analysis.

In the data analysis, the mean and standard deviations (SD) of questions used in the fivepoint scale were calculated. In order to test $\mathrm{H}_{1}$, $\mathrm{H}_{2}, \mathrm{H}_{3}$ and $\mathrm{H}_{4}$ hypotheses and determine the target groups characteristics who have more positive attitudes towards mobile marketing tools, one-sample $T$-test, independent-samples $T$-test and one-way analysis of variance (ANOVA) were used. The LSD (Least Significant Differences) test for post hoc comparisons was also chosen. Before the independent-samples $T$-test analysis, whether the dependent variable is normally distributed, and whether or not two variables (between non-internet users and internet users or females 
Table 2: Correlation matrix

\begin{tabular}{|c|c|c|c|c|c|c|c|c|}
\hline Mobile marketing tools & a & b & c & d & e & $\mathbf{f}$ & g & $\mathbf{h}$ \\
\hline a. Mobile advertising & 1 & & & & & & & \\
\hline b. Mobile discount coupons & $0.636^{\star \star}$ & 1 & & & & & & \\
\hline $\begin{array}{l}\text { c. Mobile entertainment } \\
\text { services }\end{array}$ & $0.727^{\star *}$ & $0.619^{\star *}$ & 1 & & & & & \\
\hline $\begin{array}{l}\text { d. Location-based mobile } \\
\text { services }\end{array}$ & $0.738^{\star *}$ & $0.904^{\star \star}$ & $0.733^{\star \star}$ & 1 & & & & \\
\hline e. Mobile internet & $0.232^{\star *}$ & $0.096^{*}$ & $0.156^{\star \star}$ & $0.105^{\star}$ & 1 & & & \\
\hline f. Mobile banking & $0.442^{\star \star}$ & $0.371^{\star \star}$ & $0.561^{\star \star}$ & $0.117^{\star}$ & $0.356^{\star \star}$ & 1 & & \\
\hline g. Mobile shopping & $0.258^{\star *}$ & $0.201^{\star *}$ & $0.267^{\star \star}$ & $0.282^{\star \star}$ & $0.123^{\star}$ & $0.486^{\star \star}$ & 1 & \\
\hline h. Overall mobile marketing & $0.785^{\star \star}$ & $0.775^{\star \star}$ & $0.765^{\star \star}$ & $0.841^{\star \star}$ & $0.477^{\star \star}$ & $0.339^{\star \star}$ & $0.511^{\star \star}$ & 1 \\
\hline
\end{tabular}

${ }^{*}$ Correlation is significant at the 0.05 level (two-tailed).

${ }^{\star \star}$ Correlation is significant at the 0.01 level (two-tailed).

Table 3: Respondents' profiles

\begin{tabular}{|c|c|c|c|c|c|}
\hline Variable & Frequency & (\%) & Variable & Frequency & (\%) \\
\hline Gender & & & Education & & \\
\hline Female & 148 & 35.4 & Primary School & 24 & 5.7 \\
\hline Male & 270 & 65.6 & High School & 181 & 43.3 \\
\hline Age & & & College & 76 & 18.2 \\
\hline$\leqslant 20$ & 36 & 8.6 & Undergraduate or Graduate & 137 & 32.8 \\
\hline $21-30$ & 143 & 34.2 & Employment & & \\
\hline $31-40$ & 156 & 37.3 & Official (Public) & 148 & 35.4 \\
\hline $41-50$ & 62 & 14.8 & Worker (Private) & 57 & 13.6 \\
\hline$\geqslant 51$ & 21 & 5.0 & Self-employed & 126 & 30.1 \\
\hline Monthly income & & & Tradespeople and Merchant & 37 & 8.9 \\
\hline$\leqslant \$ 350$ & 64 & 15.3 & Students & 33 & 7.9 \\
\hline$\$ 351-750$ & 135 & 32.3 & Others & 17 & 4.1 \\
\hline$\$ 751-1,500$ & 163 & 39.0 & Shopping orientations & & \\
\hline$\$ 1,501-3,000$ & 41 & 9.8 & Price-conscious customers & 307 & 73.4 \\
\hline$\geqslant \$ 3,001$ & 15 & 3.6 & Involved customers & 43 & 10.3 \\
\hline Internet usage & & & Distinctive customers & 32 & 7.7 \\
\hline Internet user & 178 & 42.6 & Recreational customers & 26 & 6.2 \\
\hline Non-internet user & 240 & 57.4 & Uninvolved customers & 10 & 2.4 \\
\hline
\end{tabular}

and males) have approximately equal variance on the dependent variable were checked by looking at Levene's Tests that were not significant $(p>0.05)$, and the variances of independent variables were approximately equal.

\section{Research results}

Among the 440 questionnaires returned, 22 were not used due to their incompleteness. The remaining 418 questionnaires were analysed by SPSS and included in the final data analysis, thereby yielding a usable response rate of about 95 per cent.

As can be seen in Table 3, among the 418 respondents, 35.4 per cent are females and 65.6 per cent are males. In terms of the respondents' employment, 35.4 per cent work as officers in public institutions, 30.1 per cent work in their own business and 13.6 per cent work in private companies, 8.9 per cent are tradespeople and merchants. 43.3 per cent of the respondents have high school degrees, 34.7 per cent have primary school degrees and 22.4 per cent have undergraduate or graduate degrees. Thirty-nine per cent of the respondents' command a monthly salary of $\$ 751-1,500 ; 32.3$ per cent of the respondents of between $\$ 351$ and 750 , and 15.3 per cent $\$ 350$ or below. Of all the 418 respondents, 42.6 per cent connect the internet from their homes, businesses or offices and - 
importantly - 57.4 per cent do not have any access to the internet. Currently, 240 respondents are non-internet users. In terms of the respondents' shopping orientations, among 418 respondents, 73.4 per cent are price-conscious customers who are interested in getting the lowest prices for their shopping; 10.3 per cent are involved customers who spend many times and compare the characteristics of products and services for their shopping; 7.7 per cent are distinctive customers who prefer shopping at special places and receive personalised service; 6.2 per cent are recreational customers who derive pleasure in shopping around; and 2.4 per cent are uninvolved customers who do not compare products and services (Table 3 ).

According to the 20 attitude statements towards mobile marketing tools, the respondents have positive attitudes towards mobile advertising, mobile discount coupons, mobile entertainment services, location-based mobile services, mobile internet and mobile banking. They have negative attitudes toward mobile shopping. They do not find mobile shopping useful. Provided that they have enough time, they prefer traditional shopping. Moreover, the respondents are of the opinion that mobile shopping poses some security problems. For those who use mobile phones for shopping, the price of products and services is their primary shopping motivation (Table 4).

\section{Hypothesis testing}

Hypotheses $\mathrm{H}_{1}-\mathrm{H}_{4}$ are now empirically tested, with Tables $5-8$ summarising the results of the one-sample $T$-tests, independent $T$-tests and oneway ANOVA.

$\mathbf{H}_{1}$ : Mobile phone users have positive attitudes towards mobile marketing tools.

$\mathrm{H}_{1 \mathrm{a}}, \mathrm{H}_{1 \mathrm{~b}}, \mathrm{H}_{1 \mathrm{c}}, \mathrm{H}_{1 \mathrm{~d}}, \mathrm{H}_{1 \mathrm{e}}, \mathrm{H}_{1 \mathrm{f}}, \mathrm{H}_{1 \mathrm{~g}}$ and $\mathrm{H}_{1}$ are separately tested. Because consumers' attitudes towards mobile marketing tools are measured in several questions, the average scores of the attitude statements are calculated for hypotheses testing. According to a sample $T$-test, respondents have positive attitudes towards mobile advertising $(t=20.866, p<0.05)$, mobile discount coupons $(t=12.531, p<0.05)$, mobile entertainment $(t=13.776, p<0.05)$, location-based mobile services $(t=13.779, p<0.05)$, mobile internet $(t=7.004, p<0.05)$ and mobile banking $(t=6.052$, $p<0.05)$. Nevertheless, they have negative attitudes towards mobile shopping $(t=-44.689$, $p>0.05)$. If all mobile marketing activities are evaluated, they seem to have positive attitudes

Table 4: Descriptive statistics of attitude statements

\begin{tabular}{|c|c|c|}
\hline Mobile marketing services & Mean & SD \\
\hline a. Mobile advertising & 4.2967 & 0.61402 \\
\hline b. Mobile discount coupons & 4.1627 & 0.80382 \\
\hline $\begin{array}{l}\text { c. Mobile entertainment } \\
\text { services }\end{array}$ & 4.1256 & 0.67617 \\
\hline $\begin{array}{l}\text { d. Location-based mobile } \\
\text { services }\end{array}$ & 4.1854 & 0.76475 \\
\hline e. Mobile internet & 4.06 & 1.152 \\
\hline f. Mobile banking & 3.9836 & 0.75342 \\
\hline g. Mobile shopping & 2.6694 & 0.45778 \\
\hline h. Overall mobile marketing & 3.8069 & 0.47134 \\
\hline
\end{tabular}

Table 5: One-sample $T$-test for mobile phone users' attitudes towards mobile marketing

\begin{tabular}{|c|c|c|c|c|}
\hline \multirow[t]{2}{*}{ Mobile marketing tools } & \multicolumn{3}{|c|}{ Test value $=3.67$} & \multirow{2}{*}{$\begin{array}{l}\text { Alternative } \\
\text { hypotheses }\end{array}$} \\
\hline & Mean & $t$ & p (Sig. 2-tailed) & \\
\hline a. Mobile advertising & 4.2967 & 20.866 & $0.000^{*}$ & $\mathrm{H}_{1 \mathrm{a}}$ (Accept) \\
\hline b. Mobile discount coupons & 4.1627 & 12.531 & $0.000^{*}$ & $\mathrm{H}_{1 \mathrm{~b}}($ Accept $)$ \\
\hline c. Mobile entertainment services & 4.1256 & 13.776 & $0.000^{*}$ & $\mathrm{H}_{1 \mathrm{c}}$ (Accept) \\
\hline d. Location-based mobile services & 4.1854 & 13.779 & $0.000^{*}$ & $\mathrm{H}_{1 d}$ (Accept) \\
\hline e. Mobile internet & 4.06 & 7.004 & $0.001^{*}$ & $\mathrm{H}_{1 \mathrm{e}}$ (Accept) \\
\hline f. Mobile banking & 3.9836 & 6.052 & $0.001^{*}$ & $\mathrm{H}_{1 f}$ (Accept) \\
\hline g. Mobile shopping & 2.6694 & -44.689 & - & $\mathrm{H}_{1 \mathrm{~g}}$ (Reject) \\
\hline h. Overall mobile marketing & 3.8069 & 5.095 & $0.003^{*}$ & $\mathrm{H}_{1}$ (Accept) \\
\hline
\end{tabular}

${ }^{*} p<0.05$. 
Table 6: Variance analysis of respondents' profile for mobile entertainment services

\begin{tabular}{|c|c|c|c|c|c|}
\hline Respondents' profile & Mean & $\boldsymbol{F}$ & $p$ & $\begin{array}{l}\text { Post hoc tests } \\
\text { (LSD test) }\end{array}$ & $\begin{array}{l}\text { Alternative } \\
\text { hypotheses by }\end{array}$ \\
\hline $\begin{array}{l}\text { Gender } \\
\text { Female } \\
\text { Male }\end{array}$ & $\begin{array}{l}4.1672 \\
4.1028\end{array}$ & 0.932 & 0.352 & - & $\mathrm{H}_{2 \mathrm{c}}$ (Reject) \\
\hline $\begin{array}{l}\text { Age } \\
\quad \leq 20 \\
21-30 \\
31-40 \\
41-50 \\
\quad \geqslant 51\end{array}$ & $\begin{array}{l}4.0347 \\
4.2430 \\
4.0962 \\
4.0081 \\
4.0476\end{array}$ & 4.137 & $0.003^{*}$ & $\begin{array}{l}(1,2) \\
(2,1)(2,3)(2,4)(2,5) \\
(3,2) \\
(4,2) \\
(5,2)\end{array}$ & $\mathrm{H}_{2 \mathrm{c}}$ (Accept) \\
\hline $\begin{array}{l}\text { Monthly income } \\
\quad \leqslant \$ 350 \\
\$ 351-750 \\
\$ 751-1,500 \\
\$ 1,501-3,000 \\
\geqslant \$ 3,001\end{array}$ & $\begin{array}{l}4.1222 \\
4.1227 \\
4.1445 \\
4.1062 \\
4.0691\end{array}$ & 1.546 & 0.168 & & $\mathrm{H}_{2 \mathrm{c}}$ (Reject) \\
\hline $\begin{array}{l}\text { Education } \\
\text { Primary School } \\
\text { High School } \\
\text { College } \\
\text { Undergraduate or Graduate }\end{array}$ & $\begin{array}{l}3.7033 \\
4.1031 \\
4.1456 \\
4.2183\end{array}$ & 2.379 & $0.037^{\star}$ & $\begin{array}{l}(1,2)(1,3)(1,4) \\
(2,1) \\
(3,1) \\
(4,1)\end{array}$ & $\mathrm{H}_{2 \mathrm{c}}$ (Accept) \\
\hline $\begin{array}{l}\text { Employment } \\
\text { Official (Public) } \\
\text { Worker (Private) } \\
\text { Self-employed } \\
\text { Tradespeople and Merchant } \\
\text { Students } \\
\text { Others }\end{array}$ & $\begin{array}{l}4.1741 \\
4.1127 \\
4.0301 \\
4.0552 \\
4.3681 \\
4.1378\end{array}$ & 2.615 & $0.017^{*}$ & $\begin{array}{l}(1,3)(1,4) \\
(3,1)(3,5) \\
(4,1)(4,5) \\
(5,3)(5,4)\end{array}$ & $\mathrm{H}_{2 \mathrm{c}}$ (Accept) \\
\hline $\begin{array}{l}\text { Shopping orientations } \\
\text { Price-conscious customers } \\
\text { Involved customers } \\
\text { Distinctive customers } \\
\text { Recreational customers } \\
\text { Uninvolved customers }\end{array}$ & $\begin{array}{l}4.1194 \\
4.0806 \\
4.1741 \\
4.2397 \\
4.0567\end{array}$ & 1.328 & 0.272 & & $\mathrm{H}_{3 c}($ Reject $)$ \\
\hline $\begin{array}{l}\text { Internet usage } \\
\text { Internet user } \\
\text { Non-Internet user }\end{array}$ & $\begin{array}{l}4.1135 \\
4.1346\end{array}$ & -0.264 & 0.792 & - & $\mathrm{H}_{4 \mathrm{c}}$ (Reject) \\
\hline
\end{tabular}

${ }^{*} p<0.05$.

towards mobile marketing tools $(t=5.095$, $p<0.05$ ), except for mobile shopping (Table 5).

$\mathbf{H}_{2}$ : There are differences between respondents' demographics characteristics and attitudes towards mobile marketing tools.

Each of the demographic characteristics (gender, age, income, education and employment), internet usage and shopping orientation of respondents were analysed separately using independent- samples T-tests and one-way ANOVA for each of the dependent variables. However, for reasons of space, only one table (Table 6) (analysing customer attitudes toward mobile entertainment services) is presented in detail. The results of independent-samples $T$-tests and one-way ANOVA are presented in Tables 7 and 8 .

There are some significant differences between respondents' profile and attitude towards mobile entertainment services. The results of the LSD helped to see exactly which groups were 
significantly different as follows: respondents who are 20-30 years old, have undergraduate or graduate degrees and are students have more positive attitudes than other groups towards mobile entertainment services. The results showed no significant differences between respondents' gender, age, income, education, employment, shopping orientations and internet usage and their attitudes towards mobile advertising, mobile discount coupons and mobile shopping $(p>0.05)$, thereby rejecting hypotheses $\mathrm{H}_{2 \mathrm{a}}, \mathrm{H}_{2 \mathrm{~b}}$ and $\mathrm{H}_{2 \mathrm{~g}}$. Nonetheless, there are statistically significant differences in location-based mobile services, mobile internet, mobile banking and overall mobile marketing. In other words, in some age, income, employment and education groups, the mean value of attitudes towards mobile internet, mobile banking and overall mobile marketing was significantly different $(p<0.05)$, thereby confirming hypotheses $\mathrm{H}_{2 \mathrm{c}}, \mathrm{H}_{2 \mathrm{~d}}, \mathrm{H}_{2 \mathrm{e}}, \mathrm{H}_{2 \mathrm{f}}$ and $\mathrm{H}_{2}$.

Respondents over 31 have more positive attitudes towards location-based mobile services. Respondents who receive $\$ 751-1,500$ and $\$ 1,501-3,000$ monthly incomes have more positive attitudes towards mobile internet and mobile banking, respectively. Respondents who have primary and high school degrees have less positive attitudes towards mobile entertainment services and the mobile internet. Respondents who are officials in public institutions and who are self-employed (accountants, doctor, engineers, etc) have a more positive attitude towards the mobile internet and mobile banking (Table 7).

$\mathbf{H}_{3}$ : There are differences between respondent's shopping orientations and attitudes towards mobile marketing tools.

In testing $\mathrm{H}_{3}$, the results displayed significant differences between respondents' shopping orientations and their attitudes towards mobile advertising, mobile discount coupons, mobile banking and mobile marketing $(p<0.05)$, thereby accepting hypotheses $\mathrm{H}_{3 \mathrm{a}}, \mathrm{H}_{3 \mathrm{~b}}$ and $\mathrm{H}_{3 \mathrm{f}}$ and $\mathrm{H}_{3}$. The results of the LSD suggest that respondents who are price-conscious, and 'involved' customers have a more positive attitude towards mobile advertising, mobile discount coupons, mobile banking and mobile marketing (Table 8).

$\mathbf{H}_{4}$ : There are differences between noninternet users' and internet users' attitudes towards mobile marketing tools.

In testing $\mathrm{H}_{4}$, to compare mobile phone users' attitudes who have a fixed-line internet connection and those who do not, independent-

Table 7: Differences between demographic characteristics of respondents and their attitudes towards mobile marketing tools

\begin{tabular}{|c|c|c|c|c|c|c|c|c|c|c|}
\hline \multirow{2}{*}{$\begin{array}{l}\text { Demographics } \\
\text { characteristics } \\
\text { Variables }\end{array}$} & \multicolumn{2}{|l|}{ Gender } & \multicolumn{2}{|l|}{ Age } & \multicolumn{2}{|c|}{ Income } & \multicolumn{2}{|c|}{ Education } & \multicolumn{2}{|c|}{ Employment } \\
\hline & $t^{\star \star}$ & $p$ & $\boldsymbol{F}$ & $p$ & $\bar{F}$ & $p$ & $\boldsymbol{F}$ & $p$ & $\bar{F}$ & $p$ \\
\hline $\begin{array}{l}\text { a. Mobile } \\
\text { advertising }\end{array}$ & -0.567 & 0.571 & 1.125 & 0.344 & 1.172 & 0.333 & 1.017 & 0.310 & 1.457 & 0.145 \\
\hline $\begin{array}{l}\text { b. Mobile discount } \\
\text { coupons }\end{array}$ & -0.264 & 0.792 & 1.868 & 0.115 & 1.674 & 0.127 & 1.129 & 0.284 & 1.441 & 0.169 \\
\hline $\begin{array}{l}\text { c. Mobile } \\
\text { entertainment } \\
\text { services }\end{array}$ & 0.932 & 0.352 & 4.137 & $0.003^{*}$ & 1.546 & 0.168 & 2.379 & $0.037^{*}$ & 2.615 & $0.017^{*}$ \\
\hline $\begin{array}{l}\text { d. Location-based } \\
\text { mobile services }\end{array}$ & 0.142 & 0.887 & 4.253 & $0.002^{*}$ & 1.424 & 0.204 & 1.004 & 0.413 & 1.193 & 0.417 \\
\hline e. Mobile internet & 1.820 & 0.069 & 0.971 & 0.423 & 2.985 & $0.028^{*}$ & 3.487 & $0.007^{*}$ & 2.313 & $0.024^{*}$ \\
\hline f. Mobile banking & -0.530 & 0.596 & 1.672 & 0.101 & 2.647 & $0.036^{*}$ & 0.974 & 0.541 & 3.617 & $0.005^{*}$ \\
\hline $\begin{array}{l}\text { g. Mobile } \\
\text { shopping }\end{array}$ & 0.342 & 0.733 & 1.013 & 0.400 & 1.216 & 0.314 & 1.185 & 0.258 & 0.742 & 0.486 \\
\hline $\begin{array}{l}\text { h. Overall mobile } \\
\text { marketing }\end{array}$ & 0.568 & 0.591 & 3.268 & $0.012^{*}$ & 1.461 & 0.214 & 0.951 & 0.514 & 2.416 & $0.021^{*}$ \\
\hline
\end{tabular}

${ }^{*} p<0.05$.

${ }^{\star *}$ Equal variance is assumed. 
Table 8: Differences between non-internet users and internet users and between their shopping orientations and attitudes towards mobile marketing tools

\begin{tabular}{lllll}
\hline Demographics characteristics & \multicolumn{2}{l}{ Shopping orientations } & \multicolumn{2}{l}{ Internet users or not } \\
\cline { 2 - 3 } \cline { 5 - 6 } Variables & $\boldsymbol{F}$ & $\boldsymbol{p}$ & & $\boldsymbol{p}$ \\
\hline a. Mobile advertising & 6.478 & $0.000^{\star}$ & -0.454 & 0.611 \\
b. Mobile discount coupons & 2.143 & $0.024^{\star}$ & 0.967 & 0.303 \\
c. Mobile entertainment services & 1.328 & 0.272 & -0.264 & 0.792 \\
d. Location-based mobile services & 1.253 & 0.142 & 0.211 & 0.719 \\
e. Mobile internet & 1.109 & 0.413 & 3.698 & $0.004^{\star}$ \\
f. Mobile banking & 4.137 & $0.003^{\star}$ & -0.819 & 0.457 \\
g. Mobile shopping & 1.364 & 0.237 & 3.019 & $0.017^{\star}$ \\
h. Overall mobile marketing & 3.827 & $0.013^{\star}$ & 2.568 & 0.129 \\
\hline
\end{tabular}

${ }^{*} p<0.05$.

${ }^{\star \star}$ Equal variance is assumed.

samples $T$-tests were performed to determine the differences between them. The results of testing the mean differences of the internet users and non-internet users are reported in Table 8. The statistics suggest that internet users and noninternet users' attitudes towards mobile tools appear to display notable differences. Noninternet users have more positive attitudes towards the mobile internet $(t=3.698, p<0.05)$, mobile shopping $(t=3.019, p<0.05)$ and mobile marketing tools overall $(t=2.568, p<0.05)$, while showing much the same attitudes as those with fixed-line internet access towards mobile advertising, mobile discount coupons, mobile entertainment, location-based mobile services and mobile banking. As a result, $\mathrm{H}_{4 \mathrm{e}}, \mathrm{H}_{4 \mathrm{~g}}$ and $\mathrm{H}_{4}$ are accepted (Table 8).

Consequently, as the statistics make clear, priceconscious customers have more positive attitudes towards mobile advertising, discount coupons, banking and mobile marketing tools overall, and respondents without fixed-line internet access differ considerably in terms of their attitude towards mobile advertising, entertainment and shopping.

\section{Managerial implications}

Developing successful marketing strategies requires identifying and focusing on the right target customers because mobile marketing programmes are characterised by fixed and variable costs.

Given this fact, it is essential to designate customer profiles holding a more positive attitude towards mobile marketing tools in order to bring down marketing costs and boost efficiency, rather than carrying out mass mobile marketing programmes. In the light of these characteristics, the target mobile segment/segments should be selected, and customised marketing strategies for these customers' groups should be tailored. Independent-samples $T$-test and one-way ANOVA were used to determine which mobile phone users within this study demonstrated the most positive attitudes towards mobile marketing tools.

While the overall respondent profile held a positive attitude towards mobile marketing tools and services, they had negative attitudes towards mobile shopping (which might be countered by offering lower prices and discount coupons). Generally, the mobile phone users who are young and middle-aged, receive a high income, work as officials in public institutions, are self-employed, have an undergraduate or a graduate degree, are price-conscious and currently non-internet users are the most important target customers for overall mobile marketing. Specifically, a sharp contrast is drawn between current non-internet users and internet users. Mobile phone users with no internet connection turn out to be more enthusiastic about the mobile internet and mobile shopping than internet users. But all mobile phone users are target customers for mobile advertising and mobile discount coupons. Further, mobile phone users who are 20-30 years old, have undergraduate or graduate degrees and are students appear to be the most outstanding target customers for mobile entertainment services. 
Mobile phone users over 31 with undergraduate or graduate degrees are the most important target customers for location-based mobile services. Mobile phone users who work in public institutions, are self-employed, work as merchants, are price-conscious and recreational customers and non-internet users are the target customers for mobile internet and mobile banking.

\section{CONCLUSION}

The internet has proven to be an efficient way of communicating, marketing and selling products and services. In parallel with the internet, mobile communications and $3 \mathrm{G}$ (Third Generation) technologies have emerged to play a key role in business, and notably direct marketing, and so emerging wireless mobile technology has been expected to bring several opportunities for marketers. If mobile commerce is adopted by mobile phone users, mobile retailers will gain a new revenue-generating direct marketing tool, in succession to the internet.

Even though it is too early to decide whether mobile commerce and mobile marketing services will be adopted or not in Turkey, the results of the survey help in establishing that mobile commerce acceptance level is low, and that mobile phone users are not ready to embrace mobile marketing in its fullest sense. Specifically, mobile phone users have a negative attitude towards mobile shopping and are found to be somewhat ignorant of it. Because mobile commerce is a very recent concept, mobile phone users have not adopted mobile shopping in combination with the mobile phone. On the other hand, mobile advertising, mobile discount coupons, mobile entertainment services, locationbased mobile services, mobile internet and mobile banking are more positively accepted by mobile phone users.

There are factors that may play a role in improving attitudes towards and increasing the take-up of mobile commerce. For example, if mobile phone users are convinced of the usefulness and utility of using mobile phones for mobile shopping, the acceptance level of mobile shopping will probably be increased. Besides mobile service quality, Bauer et al. ${ }^{12}$ emphasise that entertainment value, information value and advertising content communication are some of the strongest drivers of the acceptance of the mobile phone as a marketing tool. One of the ways to convince mobile phone users of the benefits of mobile commerce is the price of products and services. One of the implications of this survey suggests that potential mobile commerce users have price sensitivity, and that the lower price turns out to be the most critical factor that motivates mobile phone users' adoption of mobile commerce. Therefore, lower price strategy is the key to convince them of mobile commerce and to get their acceptance level increased.

At the market level, future growth in mobile commerce depends on (1) creating a favourable shopping environment by GSM operators or companies, (2) increasing mobile phones' operational efficiency and customer interaction, (3) reducing the potential risks for credit card security, fraudulent sales and order fulfilment and (4) targeting the mobile phone users who have more positive attitudes towards mobile marketing tools. As long as these requirements are fulfilled, the acceptance level of mobile commerce will keep increasing. In further research, target mobile phone users, their demographic characteristics and which products and services are preferred for mobile shopping should be identified in new surveys in different areas, cities and countries, and the strategies for implementing mobile commerce and mobile marketing should be analysed as well.

\section{References}

1 Scharl, A., Dickinger, A. and Murphy, J. (2005) 'Diffusion and success factors of mobile marketing', Electronic Commerce Research and Applications, Vol. 4, No. 2, pp. 159-173.

2 Yuan, S. T. and Cheng, C. (2004) 'Ontology-based personalized couple clustering for heterogeneous product recommendation in mobile marketing', Expert Systems with Applications, Vol. 26, No. 4, pp. 461-476.

3 E-Business Report (2000) 'Mobile E-business-Mobile commerce', European Commission Enterprise Directorate General, No. 3, Brussels, Belgium.

4 Siau, K., Lim, E. P. and Shen, Z. (2001) 'Mobile commerce: Promises, challenges, and research agenda', Journal of Database Management, Vol. 12, No. 3, pp. 4-13.

5 Clarke, I. (2001) 'Emerging value propositions for mobile commerce', Journal of Business Strategies, Vol. 18, No. 2, pp. 133-148. 
6 Frolick, M. N. and Chen, L. D. (2004) 'Assessing mobile commerce opportunities', Information Systems Management, Vol. 21, No. 2, pp. 53-61.

7 Dholakia, R. R. and Dholakia, N. (2004) 'Mobility and markets: Emerging outlines of mobile commerce', Journal of Business Research, Vol. 57, No. 12, pp. 1391-1396.

8 Bai, L., Chou, D. C., Yen, C. D. and Lin, B. (2005) 'Mobile commerce: Its market analyses', International Journal Mobile Communications, Vol. 3, No. 1, pp. 66-81.

9 DSTI/CP (Final Directorate for Science, Technology and Industry Committee on Consumer Policy) (2006) 'Mobile commerce', OECD/OCDE 2006.

10 Aungst, S. G and Wilson, D. T. (2005) 'A primer for navigating the shoals of applying wireless technology to marketing problems', Journal of Business \& Industrial Marketing, Vol. 20, No. 2, pp. 59-69.

11 Sadeh, N. (2002) 'Mobile Commerce: Technologies, Services, and Business Models', Wiley Computer Publishing, New York, USA.

12 Bauer, H., Barnes, S., Reinhardt, T. and Neumann, M. (2005) 'Driving consumer acceptance of mobile marketing: A theoretical framework and empirical study', Journal of Electronic Commerce and Research,Vol. 6, No. 3, pp. 181-192.

13 Schnicke, S. (2002) 'The problem of personalization in location based services', retrieved 15th April, 2007 from http://groups. haas.berkeley.edu/fcsuit/Pdf-papers/Schnicke.pdf, p. 12.

14 Funk, J. L. (2005) 'The future of the mobile phone Internet: An analysis of technological trajectories and lead users in the Japanese market', Technology in Society, Vol. 27, No. 1, pp. 69-83.

15 Quah, J. T. -S. and Lim, G. L. (2002) 'Push selling - Multicast messages to wireless devices based on the publish/subscribe model', Electronic Commerce Research and Applications, Vol. 1, No. 3-4, pp. 235-246.

16 Casal, C. R., Burgelman, J. C. and Bohlin, E. (2004) 'Prospects beyond 3G', Info, Vol. 6, No. 6, pp. 359-362.

17 Barnes, S. J. (2003) 'Location-based services', e-Service Journal, Vol. 2, No. 3, pp. 59-70.

18 Pura, M. (2005) 'Linking perceived value and loyalty in locationbased mobile services', Managing Service Quality, Vol. 15, No. 6, pp. 509-538.

19 Liang, T. P. and Wei, C. P. (2004) 'Introduction to the special issue: Mobile commerce applications', International Journal of Electronic Commerce, Vol. 8, No. 3, pp. 7-17.

20 Barnes, S. J. (2002) 'The mobile commerce value chain: Analysis and future developments', International Journal of Information Management, Vol. 22, No. 2, pp. 91-108.

21 Telecommunication Authority (2007) retrieved 26th October, 2007 from http://www.tk.gov.tr/Yayin/istatistikler/ istatistik/2007/istatistik2007gsm.htm.

22 Turkish Statistical Institute - Science, Technology \& Informatics — ICT Usage Statistics (2007) retrieved 23rd November, 2007 from www.turkstat.gov.tr.

23 Barutçu, S. (2007) 'Information technology, mobile marketing and mobile commerce in consumer markets', 3rd International Conference on Business, Management and Economics, 13-17 June, Yaşar University, İzmir, Turkey.

24 Tsang, M., Ho, S. and Liang, T. (2004) 'Consumer attitudes toward mobile advertising: An empirical study', International Journal of Electronic Commerce, Vol. 8, No. 3, pp. 65-78.

25 Shimp, T. A. and Kavas, A. (1984) 'The theory of reasoned action applied to coupon usage', Journal of Consumer Research, Vol. 11, No. 3, pp. 795-809. 